\title{
A PROSPECTIVE ANALYTICAL STUDY ON LIMB SALVAGE PROCEDURES IN DIABETIC FOOT ULCERS
}

\author{
Muthuraj Subramanian1, Sangaia Raja Pandian² \\ ${ }^{1}$ Assistant Professor, Department of Surgery, Government Theni Medical College, Theni. \\ ${ }^{2}$ Assistant Professor, Department of Surgery, Government Theni Medical College, Theni.
}

\begin{abstract}
BACKGROUND

The world is currently experiencing a pandemic of diabetes mellitus, particularly of type 2 or adult onset. The magnitude of the problem of diabetes is enormous. India will have the largest number of persons with diabetes. Approximately, 15\% of these patients will develop foot problems and $1 \%$ of these patients are likely to lose a limb due to some foot pathology or the other. However, the blessing in disguise is that the foot problems seen in Indian diabetic patients are mainly neuropathic-infective and not ischaemic-infective. The latter are extraordinarily more difficult to treat than neuropathic ulcers.

This study is to assess the usefulness of various screening procedures and limb salvaging interventions in diabetic foot ulcers and to bring out strategies for prevention of future foot problems. This study is to evaluate the incidence of sensory neuropathy, vasculopathy, infection and its association to diabetic foot ulcers and to compare the effectiveness of wound healing in diabetic foot ulcers between application of platelet derived growth factor and saline dressings and between retrograde venous perfusion and intravenous administration of antibiotics.
\end{abstract}

\section{MATERIALS AND METHODS}

This study was conducted at Government Rajaji Hospital, Madurai from August 2009 to August 2011. It included 100 patients with diabetic foot ulcers, who got admitted in surgical wards. Sensory neuropathy was evaluated using foot imprints with Harris mat and biothesiometry. The areas of high pressure in the foot, which is marked by the presence of more ink in the imprints and a vibration perception threshold of more than $25 \mathrm{v}$ in biothesiometry are taken as presence of sensory neuropathy. A working diagnosis of lower extremity ischaemia was made by a combination of clinical and non-invasive vascular studies. Clinical signs were based on the absence of one or more foot pulses of the involved foot. Non-invasive criteria included an Ankle-Brachial Index $(\mathrm{ABI})$ of $<0.80$. Clinical signs and/or the presence of abnormal non-invasive values make a diagnosis of lower extremity vascular insufficiency. The diagnosis of infection was made using clinical criteria. All the patients were treated with insulin. In infected cases, the role of retrograde venous perfusion of antibiotic was compared with intravenous antibiotic with respect to the decrease in ulcer area on days $0,7,14,21$ and 28. Before the institution of retrograde venous perfusion, assessment of vascular status of the limb was done by Doppler study. Combination of Heparin (100 units), Sodium bicarbonate (2 mL), Piperacillin + Tazobactam (4.5 g) and Lignocaine ( $4 \mathrm{~mL}$ ) made to $120 \mathrm{~mL}$ with normal saline was injected into leg vein with application of tourniquet at the thigh for 20 minutes. Intravenous piperacillin + tazobactam alone was given in the intravenous group. Antibiotics were given for a period of 14 days in both the groups. In non-infected diabetic foot ulcers, the effectiveness of wound healing was compared between the application of platelet derived growth factor and saline dressings. Daily application of platelet derived growth factor was done for a period of one month and normal saline dressing in the control group and the ulcer area was assessed on days 0,7 , 14,21 and 28 in both the groups. Ulcer healing in all the groups were categorised as A- Completely healed, B- Improved (> 80\% reduction in ulcer area), C- Partially healed ( $<50 \%$ reduction in ulcer area) and D- Worsened. Data analysis was done with the help of computer using Epidemiological Information Package (EIP 2010) developed by Centre for Disease Control, Atlanta. Using this software range frequencies, percentages, means, standard deviations, chi-square and ' $p$ ' values were calculated with KruskalWallis chi-square test.

\section{RESULTS}

In our study, we had taken 100 patients with diabetic foot ulcer admitted in ward and they were grouped intoGroup A- Saline group- 25 patients. Group B- PDGF group- 25 patients. Group C- RGVP- 25 patients.

Group D- Intravenous group- 25 patients.

In our study foot ulcers were more common in male population, that too between the age group of 50 - 60 years. Majority (more than 60\%) of the cases in all the four groups were males. Except a single case in PDGF and another case in intravenous group, all the other 98 cases studied were of Diabetes Mellitus type 2. Mean duration of Diabetes Mellitus in all the diabetic foot ulcer patients was more than 7 years. Percentage of smokers was highest in Group B among the males. Hypertension was present in more than $50 \%$ of the patients with diabetic foot ulcers. Mean ABI- right values were less than the normal value (0.8) in all the 4 groups. The ulcer area decrease was more $(36.9+16.5)$ in the PDGP group. Two cases in the saline group and 8 cases in the PDGF group were completely healed. Two cases in RGVP group and three in intravenous group were done SSG. None of the cases were amputated.

\section{CONCLUSION}

In our study in diabetic foot ulcer by adequate control of blood sugar, proper foot care and judicious use of modalities like platelet derived growth factor application and retrograde venous perfusion of antibiotics most of the diabetic limbs can be saved.

\section{KEYWORDS}

Diabetic Foot, Infection, Ischaemia, PDGF, Limb Salvage. 
HOW TO CITE THIS ARTICLE: Subramanian M, Pandian SR. A prospective analytical study on limb salvage procedures in diabetic foot ulcers. J. Evolution Med. Dent. Sci. 2017;6(54):4086-4093, DOI: 10.14260/Jemds/2017/883

Financial or Other, Competing Interest: None.

Submission 17-04-2017, Peer Review 21-06-2017,

Acceptance 29-06-2017, Published 06-07-2017.

Corresponding Author:

Sangaia Raja Pandian,

471/4, AMRR Compound,

Periyakulam Road,

Theni.

E-mail: sangsans77@yahoo.com

DOI: $10.14260 / \mathrm{jemds} / 2017 / 883$

\section{(c) (i) $(9$}

\section{BACKGROUND}

Diabetes mellitus virtually affects every organ system in the body and it can be well said that "Knowing diabetes is like knowing the entire human body." The Ancient Greek physician Aretaeus of Cappadocia (81 - 138 AD) was the first to use the term diabetes. The word diabetes is perhaps derived from a Greek word signifying a siphon. In 1920, Frederick Banting, Charles Best and John James Macleod first isolated insulin from the pancreas and named it isletin.

The world is currently experiencing a pandemic of diabetes mellitus, particularly of type 2 or adult onset. The magnitude of the problem of diabetes is enormous. By 2030, there will be 366 million diabetics in the world which is mainly due to longer life expectancy and change in dietary habits. India will have the largest number of persons with diabetes. Majority of these patients will be in the age group of 35 to 45 years. Approximately, $15 \%$ of these patients will develop foot problems and $1 \%$ of these patients are likely to lose a limb due to some foot pathology or the other. ${ }^{1}$ However, the blessing in disguise is that the foot problems seen in Indian diabetic patients are mainly neuropathicinfective and not ischaemic-infective. The latter are extraordinarily, more difficult to treat than neuropathic ulcers.

It is a sad fact that as of today a regular foot examination and monitoring is not routinely practiced by our people. In fact, the routine policy is- "No complaints - No examination." However, by the time the patient complains of some symptoms, the pathology is advanced and foot salvage becomes extremely difficult. Early detection and attention to warning signals in the foot definitely can salvage the limbs to a greater extent.

The diabetic foot may be defined as a group of syndromes in which neuropathy, ischaemia and infection lead to tissue break down resulting in morbidity and possible amputation." 2

"The foot of a diabetic patient that has the potential risk of pathologic consequences including infection, ulceration and/or destruction of deep tissues associated with neurologic abnormalities, various degrees of peripheral vascular disease and/or metabolic complications of diabetes in the lower limb."

This renowned institution which is well known for its academic and research activities has a very good infrastructure for managing diabetes and its associated complications. In our institution, we have a diabetology department and also a diabetic foot clinic for effective management of foot problems in diabetes.
This department has a well-equipped infrastructure, which has been rendering its services to all the diabetics of southern districts of Tamilnadu from the year 2000 onwards. It is manned by fully qualified diabetologists who are treating about 800 to 1000 diabetic patients per day as outpatients. Various screening tools like biothesiometer, Doppler probe and other sophisticated equipment are available in this department. Experts in the field of dietetics and podiatry educate our diabetic patients to have a better quality of life.

In the Department of General Surgery, we have a separate diabetic foot clinic in which we conduct separate outpatient clinics once a week. Every week we do get around $10-15$ diabetic patients with foot problems, who will get either an outpatient or inpatient treatment depending on the magnitude of their problem. In addition to this, patients with diabetic foot ulcers are being admitted in regular OPDs also. All these patients are treated according to current guidelines and recommendations. There is a separate physiotherapy department where proper foot wear is being dispensed for the diabetic patients with foot problems.

The aim of this study is to assess the usefulness of various screening procedures and limb salvaging interventions in diabetic foot ulcers and to bring out strategies for prevention of future foot problems to evaluate the incidence of sensory neuropathy, vasculopathy, infection and its association to diabetic foot ulcers and to compare the effectiveness of wound healing in diabetic foot ulcers between application of Platelet derived growth factor and Saline dressings and between Retrograde venous perfusion and Intravenous administration of antibiotics.

\section{MATERIALS AND METHODS}

This study was non-randomised controlled study with cases taken from August 2009 to August 2011. It included 100 patients with diabetic foot ulcers, who got admitted in surgical wards. Patients treated as outpatients were excluded from the study.

The diagnosis of diabetes was verified for all patients using the criteria set forth by the World Health Organization, which includes treatment with insulin, two random blood glucose measurements greater than $200 \mathrm{mg} / \mathrm{dL}$ or a fasting blood glucose greater than $126 \mathrm{mg} / \mathrm{dL}$. Age and sex of the patients, duration of diabetes and treatment taken were recorded. Presence of smoking, hypertension and other comorbidities were also noted.

All 100 patients of diabetic foot ulcers were divided into infected and non-infected cases. All patients were tested for ischaemia and sensory neuropathy.

Sensory neuropathy was evaluated using foot imprints with Harris mat and biothesiometry. The areas of high pressure in the foot, which is marked by the presence of more ink in the imprints and a vibration perception threshold of more than $25 \mathrm{v}$ in biothesiometry are taken as presence of sensory neuropathy.

A working diagnosis of lower extremity ischaemia was made by a combination of clinical and non-invasive vascular studies. Clinical signs were based on the absence of one or more foot pulses of the involved foot. Noninvasive criteria 
included an Ankle-Brachial Index $(\mathrm{ABI})$ of $<0.80$. Clinical signs and/or the presence of abnormal non-invasive values make a diagnosis of lower extremity vascular insufficiency.

The diagnosis of infection was made using clinical criteria. Wounds with frank purulence and/or two or more of the following local signs were classified as "infected." These signs include warmth, erythema, lymphangitis, lymphadenopathy, oedema and loss of function. Culture and sensitivity of the wound discharge was also done. Effective wound debridement was done in all the cases. And all the patients were treated with insulin.

Among the 50 infected cases, 25 cases were allotted for intravenous group and 25 cases were the retrograde intravenous perfusion group.

In the role of retrograde venous perfusion of antibiotic was compared with intravenous antibiotic with respect to the decrease in ulcer area on days 0, 7, 14, 21 and 28. Before the institution of retrograde venous perfusion, assessment of vascular status of the limb was done by Doppler study. Combination of Heparin (100 units), Sodium bicarbonate (2 $\mathrm{mL}$ ), Piperacillin + Tazobactam (4.5 g) and Lignocaine (4 mL) made to $120 \mathrm{~mL}$ with normal saline was injected into leg vein with application of tourniquet at the thigh for 20 minutes.

Intravenous piperacillin + tazobactam alone was given in the intravenous group. Antibiotics were given for a period of 14 days in both the groups. The inclusion criteria were- (a) Patients with infected non-healing diabetic foot ulcer, (b) Absence of venous thrombosis in the affected limb and (C) Non-oedematous limbs.

The exclusion criteria were presence of deep vein thrombosis, gangrene and difficulty in venous cannulation.

In 50 non-infected diabetic foot ulcers, the effectiveness of wound healing was compared between the application of platelet derived growth factor in 25 cases and saline dressings in 25 cases.

Daily application of platelet derived growth factor was done for a period of one month and normal saline dressing in the control group and the ulcer area was assessed on days 0 , $7,14,21$ and 28 in both the groups.

\section{Ulcer Healing in all the Groups were Categorised as-}

A- Completely healed,

B- Improved ( $>80 \%$ reduction in ulcer area),

C- Partially healed $(<50 \%$ reduction in ulcer area), and

D- Worsened.

Other treatment modalities like skin grafting and amputation were also recorded. Statistical tools, the information collected regarding all the selected cases were recorded. The risk factors and complications of all the patients were recorded and tabulated.

Data analysis was done with the help of computer using Epidemiological Information Package (EIP 2010) developed by Centre for Disease Control, Atlanta. Using this software range, frequencies, percentages, means, standard deviations, chi-square and ' $p$ ' values were calculated. Kruskal-Wallis chisquare test was used to test the significance of difference between quantitative variables and Yate's chi-square test for qualitative variables. A ' $p$ ' value less than 0.05 is taken to denote significant relationship.

\section{RESULTS}

Group A- Saline group- 25 patients.

Group B- PDGF group- 25 patients.

Group C- RGVP- 25 patients.

Group D- Intravenous group- 25 patients.

\section{A. Profile of Cases Studied}

\begin{tabular}{|c|c|c|c|c|c|c|c|c|}
\hline \multirow[t]{2}{*}{ Age Group } & \multicolumn{2}{|c|}{$\begin{array}{l}\text { Group A } \\
\text { (Saline) }\end{array}$} & \multicolumn{2}{|c|}{$\begin{array}{c}\text { Group B } \\
\text { (PDGF) }\end{array}$} & \multicolumn{2}{|c|}{$\begin{array}{c}\text { Group C } \\
\text { (RFVP) }\end{array}$} & \multicolumn{2}{|c|}{$\begin{array}{c}\text { Group D } \\
\text { (Intravenous) }\end{array}$} \\
\hline & No & $\%$ & No & $\%$ & No & $\%$ & No & $\%$ \\
\hline $\begin{array}{l}\text { Upto } 40 \\
\text { years }\end{array}$ & 6 & 24 & 2 & 8 & 3 & 12 & 4 & 16 \\
\hline $41-50$ years & 7 & 28 & 5 & 20 & 6 & 24 & 9 & 36 \\
\hline 51-60 years & 7 & 28 & 9 & 36 & 10 & 40 & 6 & 24 \\
\hline Above 60 & 5 & 20 & 9 & 36 & 6 & 24 & 6 & 24 \\
\hline Total & 25 & 100 & 25 & 100 & 25 & 100 & 25 & 100 \\
\hline Range & \multicolumn{2}{|c|}{$32-80$} & \multicolumn{2}{|c|}{$35-75$} & \multicolumn{2}{|c|}{$40-70$} & \multicolumn{2}{|c|}{$25-70$} \\
\hline Mean & & .1 & & 5.7 & & & & \\
\hline \multicolumn{9}{|c|}{ Table 1. Age Distribution } \\
\hline
\end{tabular}

Age of the patients included in the study ranged from 25 to 75 years. Mean age of the patients was between 51 to 57 years.

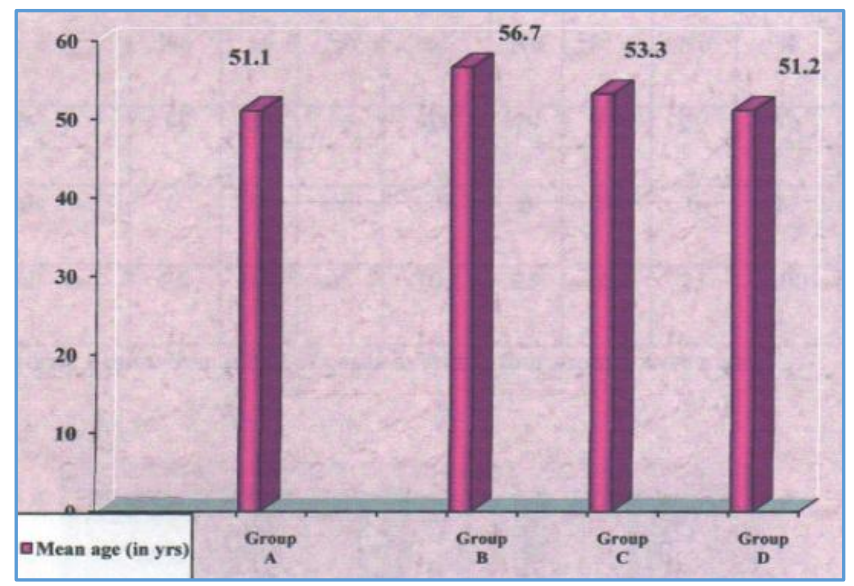

Chart 1

\begin{tabular}{|c|c|c|c|c|c|c|c|c|}
\hline \multirow{2}{*}{ Sex } & $\begin{array}{c}\text { Group A } \\
\text { (Saline) }\end{array}$ & \multicolumn{2}{c|}{$\begin{array}{c}\text { Group B } \\
\text { (PDGF) }\end{array}$} & \multicolumn{2}{c|}{$\begin{array}{c}\text { Group C } \\
\text { (RFV) }\end{array}$} & \multicolumn{2}{c|}{$\begin{array}{c}\text { Group D } \\
\text { (Intravenous) }\end{array}$} \\
\cline { 2 - 9 } & No & $\mathbf{\%}$ & No & $\mathbf{\%}$ & No & $\mathbf{\%}$ & No & $\mathbf{\%}$ \\
\hline Male & 16 & 64 & 16 & 64 & 19 & 76 & 19 & 76 \\
\hline Female & 9 & 36 & 9 & 36 & 6 & 24 & 6 & 24 \\
\hline Total & $\mathbf{2 5}$ & $\mathbf{1 0 0}$ & $\mathbf{2 5}$ & $\mathbf{1 0 0}$ & $\mathbf{2 5}$ & $\mathbf{1 0 0}$ & $\mathbf{2 5}$ & $\mathbf{1 0 0}$ \\
\hline \multicolumn{8}{|c|}{ Table 2. Sex Distribution } \\
\hline
\end{tabular}

Majority (more than 60\%) of cases in all the four groups were males. 


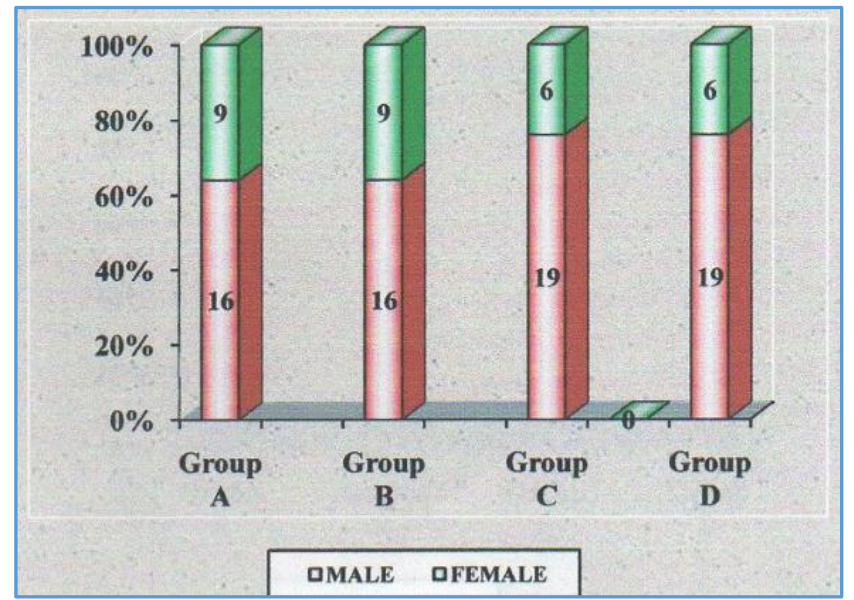

Chart 2

\begin{tabular}{|c|c|c|c|c|c|c|c|c|}
\hline \multirow{2}{*}{$\begin{array}{c}\text { Type of } \\
\text { DM }\end{array}$} & $\begin{array}{c}\text { Group A } \\
\text { (Saline) }\end{array}$ & $\begin{array}{c}\text { Group B } \\
\text { (PDGF) }\end{array}$ & $\begin{array}{c}\text { Group C } \\
\text { (RFVP) }\end{array}$ & $\begin{array}{c}\text { Group D } \\
\text { (Intravenous) }\end{array}$ \\
\cline { 2 - 9 } & No & $\mathbf{\%}$ & No & $\mathbf{\%}$ & No & $\mathbf{\%}$ & No & $\mathbf{\%}$ \\
\hline Type 1 & - & - & 1 & 4 & - & - & 1 & 4 \\
\hline Type 2 & 25 & 100 & 24 & 96 & 25 & 100 & 24 & 96 \\
\hline Total & $\mathbf{2 5}$ & $\mathbf{1 0 0}$ & $\mathbf{2 5}$ & $\mathbf{1 0 0}$ & $\mathbf{2 5}$ & $\mathbf{1 0 0}$ & $\mathbf{2 5}$ & $\mathbf{1 0 0}$ \\
\hline \multicolumn{8}{|c|}{ Table 3 } \\
\hline
\end{tabular}

Except a single case in PDGP and another case in Intravenous Group, all the other 98 cases studied were of Diabetes Mellitus type 2.

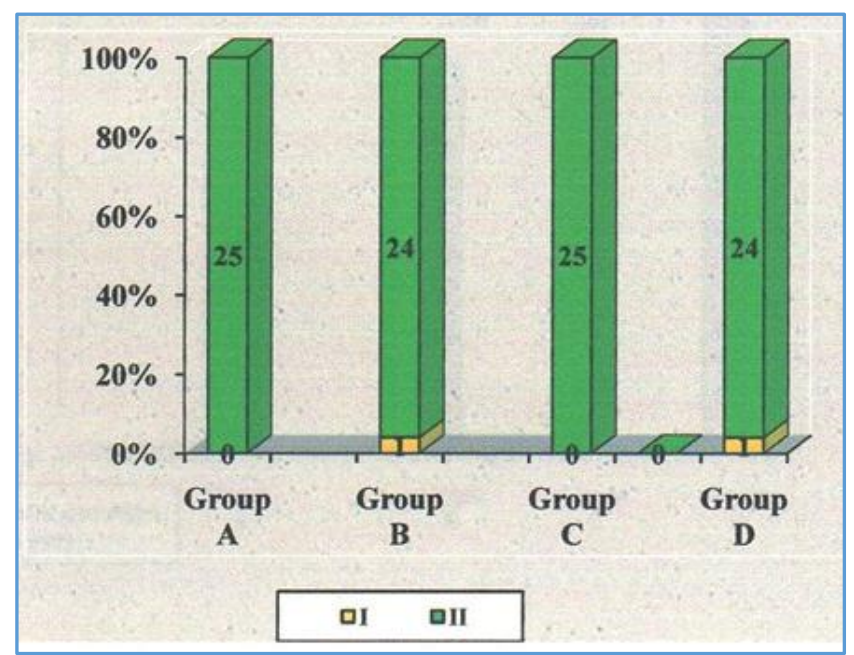

Chart 3

\begin{tabular}{|c|c|c|c|c|}
\hline $\begin{array}{c}\text { Duration of } \\
\text { DM (In } \\
\text { Years) }\end{array}$ & $\begin{array}{c}\text { Group A } \\
\text { (Saline) }\end{array}$ & $\begin{array}{c}\text { Group B } \\
\text { (PDGF) }\end{array}$ & $\begin{array}{c}\text { Group C } \\
\text { (RFVP) }\end{array}$ & $\begin{array}{c}\text { Group D } \\
\text { (Intravenous) }\end{array}$ \\
\hline Range & $4-20$ & $3-12$ & $5-12$ & $3-15$ \\
\hline Mean & 7.6 & 7.24 & 8.12 & 8.8 \\
\hline \multicolumn{4}{|c|}{ Table 4. Distribution of DM } \\
\hline
\end{tabular}

Mean duration of Diabetes Mellitus in all the diabetic foot ulcer patients was more than 7 years.

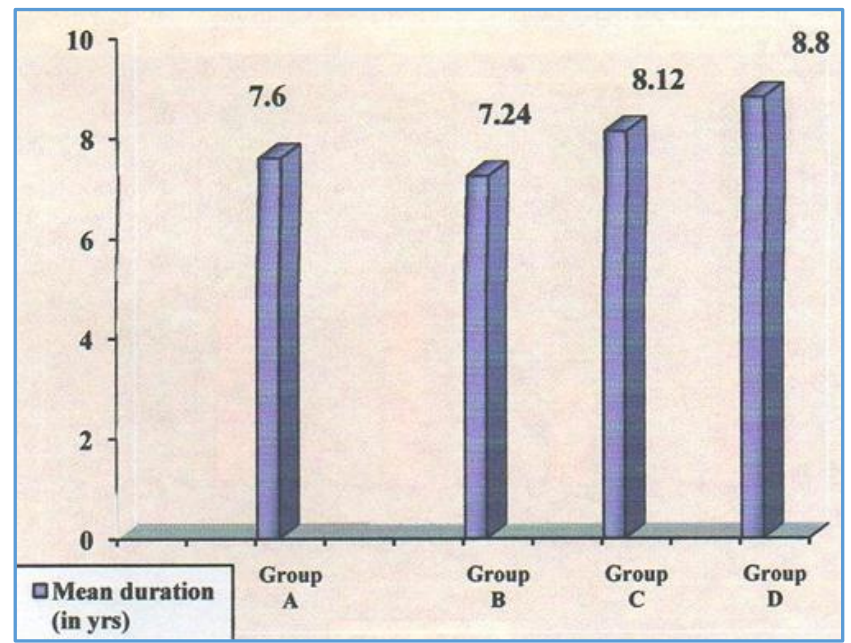

Chart 4

\section{B. Risk Factors}

\begin{tabular}{|c|c|c|c|c|c|c|c|c|}
\hline $\begin{array}{c}\text { Smoking } \\
\text { (Among } \\
\text { Males) }\end{array}$ & $\begin{array}{c}\text { Group A } \\
\text { (16) } \\
\text { (Saline) }\end{array}$ & $\begin{array}{c}\text { Group B } \\
\text { (16) } \\
\text { (PDGF) }\end{array}$ & $\begin{array}{c}\text { Group C } \\
\text { (16) } \\
\text { (RFVP) }\end{array}$ & \multicolumn{2}{c|}{$\begin{array}{c}\text { Group D } \\
\text { (16) } \\
\text { (Intravenous) }\end{array}$} \\
\cline { 2 - 8 } & No & $\mathbf{\%}$ & No & \% & No & \% & No & \% \\
\hline Yes & 8 & 50 & 9 & 56.3 & 5 & 26.3 & 7 & 36.8 \\
\hline No & 8 & 50 & 7 & 43.8 & 14 & 73.7 & 12 & 63.2 \\
\hline \multicolumn{10}{|c|}{ Table 5. Smoking (Among Males) } \\
\hline
\end{tabular}

Among the males included in the study percentages of smokers were $50 \%, 56.3 \%, 26.3 \%$ and $36.8 \%$ respectively in the four groups.

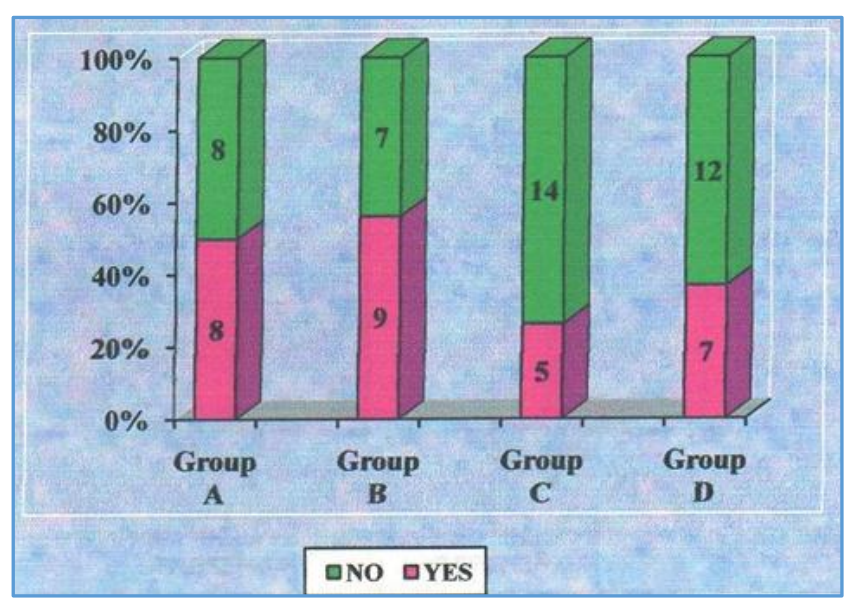

Chart 5

\begin{tabular}{|c|c|c|c|c|c|c|c|c|}
\hline \multirow{3}{*}{ HTN } & \multicolumn{2}{|c|}{$\begin{array}{c}\text { Group A } \\
\text { (Saline) }\end{array}$} & $\begin{array}{c}\text { Group B } \\
\text { (PDGF) }\end{array}$ & \multicolumn{2}{c|}{$\begin{array}{c}\text { Group C } \\
\text { (RFVP) }\end{array}$} & \multicolumn{2}{c|}{$\begin{array}{c}\text { Group D } \\
\text { (Intravenous) }\end{array}$} \\
\cline { 2 - 9 } & No & $\%$ & No & $\%$ & No & $\%$ & No & $\%$ \\
\hline Present & 16 & 64 & 12 & 48 & 14 & 56 & 12 & 48 \\
\hline Absent & 9 & 36 & 13 & 52 & 11 & 44 & 13 & 52 \\
\hline \multicolumn{8}{|c|}{ Table 6. Hypertension } \\
\hline
\end{tabular}

Hypertension was present in more than $50 \%$ of the patients with diabetic foot ulcers. 


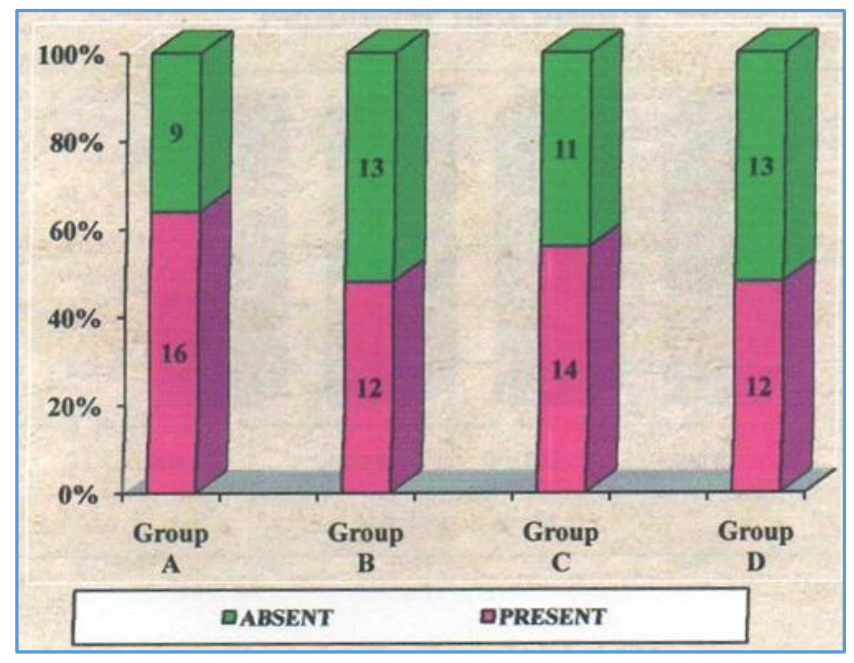

Chart 6

\begin{tabular}{|c|c|c|c|c|c|c|c|c|}
\hline \multirow{3}{*}{ PN } & $\begin{array}{c}\text { Group A } \\
\text { (Saline) }\end{array}$ & \multicolumn{2}{c|}{$\begin{array}{c}\text { Group B } \\
\text { (PDGF) }\end{array}$} & $\begin{array}{c}\text { Group C } \\
\text { (RFVP) }\end{array}$ & \multicolumn{2}{c|}{$\begin{array}{c}\text { Group D } \\
\text { (Intravenous) }\end{array}$} \\
\cline { 2 - 9 } & No & $\mathbf{\%}$ & No & $\mathbf{\%}$ & No & $\mathbf{\%}$ & No & $\%$ \\
\hline Present & 25 & 100 & 25 & 100 & 25 & 100 & 25 & 100 \\
\hline Absent & 0 & 0 & 0 & 0 & 0 & 0 & 0 & 0 \\
\hline \multicolumn{8}{|c|}{ Table 7. Peripheral Neuropathy } \\
\hline
\end{tabular}

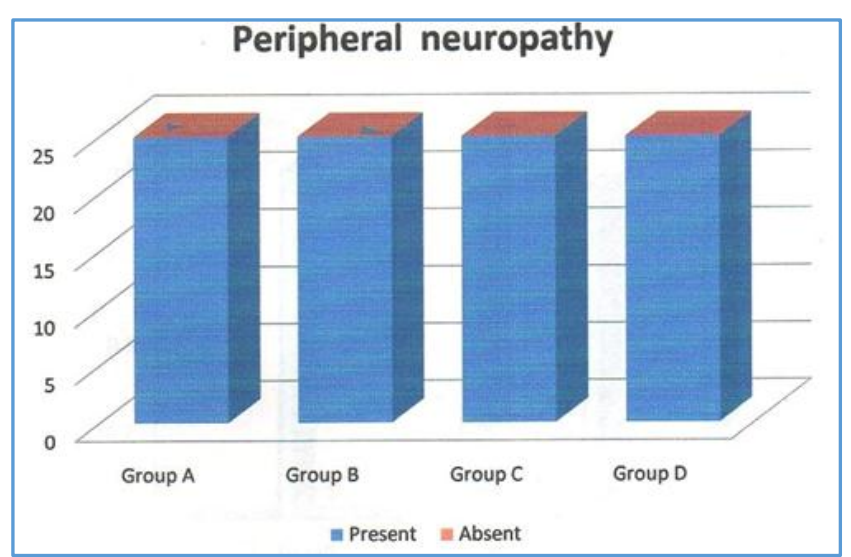

Chart 7

\begin{tabular}{|c|c|c|c|c|}
\hline $\begin{array}{c}\text { ABI Values } \\
\text { Right }\end{array}$ & $\begin{array}{c}\text { Group A } \\
\text { (Saline) }\end{array}$ & $\begin{array}{c}\text { Group B } \\
\text { (PDGF) }\end{array}$ & $\begin{array}{c}\text { Group C } \\
\text { (RFVP) }\end{array}$ & $\begin{array}{c}\text { Group D } \\
\text { (Intravenous) }\end{array}$ \\
\hline Range & $0.6-1$ & $0.6-1$ & $0.6-1$ & $0.6-1$ \\
\hline Mean & 0.79 & 0.73 & 0.75 & 0.76 \\
\hline S.D & 0.15 & 0.11 & 0.13 & 0.15 \\
\hline \multicolumn{5}{|c|}{ Table 8. ABI Values Right } \\
\hline
\end{tabular}

Mean ABI - right values were less than the normal value $(0.8)$ in all the 4 Groups.

\begin{tabular}{|c|c|c|c|c|}
\hline $\begin{array}{c}\text { ABI - } \\
\text { Left }\end{array}$ & $\begin{array}{c}\text { Group A } \\
\text { (Saline) }\end{array}$ & $\begin{array}{c}\text { Group B } \\
\text { (PDGF) }\end{array}$ & $\begin{array}{c}\text { Group C } \\
\text { (RFVP) }\end{array}$ & $\begin{array}{c}\text { Group D } \\
\text { (Intravenous) }\end{array}$ \\
\hline Range & $0.6-1.0$ & $0.6-1.0$ & $0.5-1.0$ & $0.6-1.0$ \\
\hline Mean & 0.7 & 0.74 & 0.72 & 0.72 \\
\hline S.D & 0.1 & 0.13 & 0.14 & 0.11 \\
\hline \multicolumn{5}{|c|}{ Table 9. ABI - Left } \\
\hline
\end{tabular}

Mean ABI - left values were less than the normal value (0.8) in all the 4 Groups.

\section{Comparative Efficacy of Saline and PDGE Methods}

\begin{tabular}{|c|c|c|c|}
\hline \multirow{2}{*}{$\begin{array}{c}\text { Ulcer Area } \\
\left(\mathbf{c m}^{2} \text { ) at }\right.\end{array}$} & $\begin{array}{c}\text { Saline } \\
\text { Group }\end{array}$ & $\begin{array}{c}\text { PDGF } \\
\text { Group }\end{array}$ & \multirow{2}{*}{ 'P' } \\
\hline 0 day & $62.7 \pm 28.3$ & $53.2 \pm 25.6$ & 0.2297 Not Significant \\
\hline $7^{\text {th }}$ day & $55.2 \pm 27.6$ & $35 \pm 20$ & 0.0088 Significant \\
\hline $14^{\text {th }}$ day & $52.8 \pm 27.5$ & $28.7 \pm 22$ & 0.0017 Significant \\
\hline $2^{\text {st }}$ day & $43.9 \pm 26.8$ & $22 \pm 18.4$ & 0.0035 Significant \\
\hline $2^{\text {th }}$ day & $41.7 \pm 29$ & $21.2 \pm 20.9$ & 0.0063 Significant \\
\hline $\begin{array}{c}\text { Decrease in } \\
\text { 28 days }\end{array}$ & $24.0 \pm 18.6$ & $36.9 \pm 16.5$ & 0.0127 Significant \\
\hline \multicolumn{3}{|c|}{ Table 10. Ulcer Area at Different Times } \\
\hline
\end{tabular}

Ulcer area was $62.7 \pm 28.3$ sq.cms ${ }^{2}$ on the day of first visit and it was reduced by $24.0 \pm 18.6$ to $41.7 \pm 29 \mathrm{sq} . \mathrm{cms}^{2}$ at the end of four weeks in the saline group. But the decrease was more $(36.9 \pm 16.5)$ in the PDGP group. This difference was statistically significant $(\mathrm{p}=0.0127)$.

\begin{tabular}{|c|c|c|}
\hline $\begin{array}{c}\text { Healing Time for } \\
\text { Completely Healed Cases } \\
\text { (In Days) }\end{array}$ & $\begin{array}{c}\text { PDGF Group } \\
\text { (8 Cases) }\end{array}$ & Saline Group \\
\hline Range & 18-20 days & $24-26$ \\
\hline Mean & 19 & 25.0 \\
\hline
\end{tabular}

Two cases in the saline group and 8 cases in the PDGF group were completely healed.

\begin{tabular}{|c|c|c|c|c|}
\hline \multirow{2}{*}{ Type of Healing } & \multicolumn{2}{|c|}{ Saline Group } & \multicolumn{2}{c|}{ PDGF Group } \\
\cline { 2 - 5 } & No. & $\mathbf{\%}$ & No. & \% \\
\hline Completely healed & 2 & 8 & 8 & 32 \\
\hline Improved & 5 & 20 & 12 & 48 \\
\hline Partly healed & 15 & 60 & 5 & 20 \\
\hline Worsened & 3 & 12 & - & - \\
\hline P Table 12. Type of Healing \\
\hline
\end{tabular}

$80 \%$ of cases in PDGF group were improved or completely healed, whereas this figure was only $28 \%$ for saline group. Thus, PDGF was significantly $(p=0.0007)$ more effective in healing than saline group.

\begin{tabular}{|c|c|c|c|c|}
\hline \multirow{2}{*}{ SSG/AMP } & \multicolumn{2}{|c|}{ Saline Group } & \multicolumn{2}{c|}{ PDGF Group } \\
\cline { 2 - 5 } & No & \% & No & \% \\
\hline SSG & & & & \\
Done & 5 & 20 & 8 & 32 \\
Not Done & 20 & 80 & 17 & 68 \\
\hline P & \multicolumn{3}{|c|}{0.519 Not Significant } \\
\hline Amputation & \multicolumn{4}{|c|}{ 1.0 Not Significant } \\
Done & - & - & - & - \\
Not Done & 25 & 100 & 25 & 100 \\
\hline P & \multicolumn{5}{|c|}{} \\
\hline Table 13. Split Skin Grafting/Amputation \\
\hline
\end{tabular}

SSG was done for 5 cases in saline group and 8 cases in PDGF group. Amputation was not done for any case in both groups. 
D. Comparative Efficacy of RGVP and Intravenous Groups

\begin{tabular}{|c|c|c|c|}
\hline \multirow{2}{*}{$\begin{array}{c}\text { Ulcer Area } \\
\left(\mathbf{c m}^{2} \mathbf{)} \text { at }\right.\end{array}$} & $\begin{array}{c}\text { RGVP } \\
\text { Group }\end{array}$ & $\begin{array}{c}\text { Intravenous } \\
\text { Group }\end{array}$ & \multirow{2}{*}{ 'P' } \\
\cline { 2 - 4 } 0 day & $50.9 \pm 18.8$ & $61.0 \pm 23.1$ & $\begin{array}{c}0.1785 \text { Not } \\
\text { Significant }\end{array}$ \\
\hline $7^{\text {th }}$ day & $26.5 \pm 14.7$ & $46.2 \pm 19.3$ & 0.0004 Significant \\
\hline $14^{\text {th }}$ day & $18.9 \pm 11.1$ & $43 \pm 23$ & 0.0001 Significant \\
\hline $21^{\text {st }}$ day & $15.4 \pm 9.2$ & $35.5 \pm 22.7$ & 0.0003 Significant \\
\hline $28^{\text {th }}$ day & $11 \pm 9.9$ & $31.3 \pm 19.4$ & 0.0001 Significant \\
\hline $\begin{array}{c}\text { Decrease in } \\
28 \text { days }\end{array}$ & $41.9 \pm 13.9$ & $29.8 \pm 12.8$ & 0.0046 Significant \\
\hline \multicolumn{4}{|c|}{ Table 14. Ulcer Area at Different Times } \\
\hline
\end{tabular}

Ulcer area of $50.9 \pm 18.8$ sq.cms ${ }^{2}$ in RGVP group was reduced to $11 \pm 9.9$ sq. $\mathrm{cm}^{2}$ at the end of 4 weeks of treatment. But in the intravenous group, it was reduced from $61 \pm 23.1$ sq.cms ${ }^{2}$ to $29.8 \pm 12.8$ sq.cms ${ }^{2}$. The reductions were $41.9 \pm$ 13.9 and $29.8 \pm 12.8$ sq.cms ${ }^{2}$. The difference in reduction of ulcer area was statistically significant $(p=0.0046)$, substantiating the better efficacy at RGVP over intravenous treatment.

Note: None of the cases in the intravenous group were completely healed.

\begin{tabular}{|c|c|c|c|c|}
\hline \multirow{2}{*}{ Type of Healing } & \multicolumn{2}{|c|}{ RGVP Group } & \multicolumn{2}{c|}{ Intravenous Group } \\
\cline { 2 - 5 } & No & $\mathbf{\%}$ & No & $\mathbf{\%}$ \\
\hline Completely healed & 5 & 20 & - & - \\
\hline Improved & 16 & 64 & 6 & 24 \\
\hline Partly healed & 4 & 16 & 17 & 68 \\
\hline Worsened & - & - & 2 & 8 \\
\hline P & \multicolumn{4}{c|}{ 0.0001 Significant } \\
\hline \multicolumn{6}{|c}{ Table 15. Type of Healing } \\
\end{tabular}

84\% of cases in RGVP group were improved and completely healed, whereas only $24 \%$ in intravenous group were improved. Type of healing was significantly better in RGVP group ( $p=0.0001)$.

\begin{tabular}{|c|c|c|c|c|}
\hline \multirow{2}{*}{ SSG/Amputation } & \multicolumn{2}{|c|}{ RGVP Group } & \multicolumn{2}{c|}{ Intravenous Group } \\
\cline { 2 - 5 } & No & $\%$ & No & $\%$ \\
\hline SSG & & & & \\
Done & 2 & 8 & 3 & 12 \\
Not Done & 23 & 92 & 22 & 88 \\
\hline P & \multicolumn{4}{|c|}{0.5 Not Significant } \\
\hline Amputation & - & - & - & - \\
Done & 25 & 100 & 25 & 100 \\
Not Done & \multicolumn{5}{|c|}{ 1.0 Not Significant } \\
\hline P Table 16. SSG/Amputation \\
\hline \multicolumn{5}{|c}{} \\
\hline
\end{tabular}

Two cases in RGVP group and three in intravenous group were done SSG. None of the cases were amputated.

\section{DISCUSSION AND ANALYSIS}

\section{Age and Sex}

In our study, foot ulcers were more common in male population that too between the age group of $50-60$ years.
This shows the nature of work in males and the amount of trauma they are subjected to.

\section{Type and Duration of Diabetes}

Most of the patients in our study are suffering from type 2 diabetes and the mean duration of diabetes was more than 7 years. This longer duration of diabetes is directly proportional to the development of complications of diabetes like neuropathy and vasculopathy, 3,4 which are significant precursors for foot ulcers.

\section{Risk Factors}

Smoking as an individual risk factor for diabetic foot ulcer cannot be emphasised much. Instead, it accelerates the development of vasculopathy, ${ }^{5}$ which is a forerunner of foot ulcers. Nearly, $50 \%$ of the patients in our study had an associated hypertension which in turn accelerates diabetic changes in the tissues at a more rapid pace, thereby indirectly leading to foot ulcers.

\section{Neuropathy and Vasculopathy}

As it is well described in literatures, sensory neuropathy is one of the most important causative factor for development of foot ulcers in diabetics. Our study also confirms the above fact that nearly all our patients had sensory neuropathy. Vasculopathy,6,7 a major pathophysiological factor for diabetic foot ulcers was present in about $80 \%$ of our patients and in all of them the mean $\mathrm{ABI}$ was $<0.8$.

\section{PDGF vs Saline Groups}

In studies by Smiell JM, Wieinan et al and Steed et al, daily application of platelet derived growth factor in diabetic foot ulcers resulted in significant earlier reduction in ulcer area.8,9

In our study also, there was a statistically significant reduction in ulcer area of more than $40 \mathrm{~cm}^{2}$ by 4 weeks after application of platelet derived growth factor when compared to only $24 \mathrm{~cm}^{2}$ saline dressing group.

The effective wound healing with application of platelet derived growth factor was proven by the fact that nearly $80 \%$ of the ulcers treated with platelet derived growth factor were either improved or got healed completely, while only $28 \%$ of ulcers got improved in the case of saline dressing.

In completely healed wounds, the healing time was only 19 days in platelet derived growth factor group when compared to 25 days in saline group.

In patients who were in the improved group, the graft bed was better prepared for skin grafting much earlier ${ }^{10,11}$ with dressing platelet derived growth factor than with saline dressing. Hence, in larger wounds the platelet derived growth factor dressing provides early and effective wound healing, thereby avoiding the need for an extensive skin grafting. ${ }^{12,13}$ Amputations were not done in any of our patients. Platelet derived growth factor dressing is really a useful adjunct and limb salvaging modality in the management of non-healing diabetic foot ulcers.

\section{Retrograde Venous Perfusion vs Intravenous Antibiotic Groups}

The prevalence of infection in both the groups were similar as proven by positive cultures from the wound swabs. The effective concentration of antibiotic reaching the ulcer site is 
much better in the retrograde venous perfusion group compared to intravenous group. This was reflected by the reduction in ulcer area by 28 days was $41 \mathrm{~cm}^{2}$ in the retrograde venous perfusion group compared to only $29 \mathrm{~cm}^{2}$ in the intravenous group.

Nearly, about $80 \%$ of the patients in the retrograde venous perfusion group showed a statistically significant reduction in ulcer area compared to only $24 \%$ in the intravenous group.

Since effective control of infection is possible with retrograde venous perfusion of antibiotic, the ulcer healing occurs much earlier. About 5 patients in retrograde venous perfusion had complete healing of ulcer by $3^{\text {rd }}$ to $4^{\text {th }}$ week.

Skin grafting was done for 2 patients in retrograde venous perfusion group and none of these patients underwent any sort of amputations. Hence, retrograde venous perfusion of antibiotics offers an added advantage of effective drug concentration at the wound site and a better and faster wound healing compared to systemic antibiotic therapy. 14,15

\section{Preventive Strategies}

All the patients in our study are screened for the presence of high-risk pressure points in the same as well as the opposite foot. Special foot wears were prescribed to all our patients to prevent further ulcers in the same or at other sites in their foot. Education regarding foot care was given to all of them and they were advised to come for regular followup.

\section{CONCLUSION}

Diabetes mellitus which is already a public health problem needs to be addressed more effectively. The foot problems in diabetics pose a challenge not only to the treating surgeon, but to the entire society. Hence, many newer modalities of treatment are being introduced in the management of diabetic foot. There is a changing trend towards adopting limb salvaging procedures, thereby avoiding amputations as far as possible.

In our study, foot ulcers were more common in male population with fairly longer duration of diabetes. This signifies the nature of work that males in our society are exposed to and also the prolonged periods needed for the development of complications of diabetes, which are precursors for ulcers in these individuals.

Peripheral neuropathy and vasculopathy are independent risk factors for the development of diabetic ulcers. In our study, nearly all the patients had neuropathy and about $80 \%$ of our patients had vasculopathy. Hence, an adequate control of diabetes by all means is needed to prevent the development of these risk factors in a diabetic individual.

Platelet derived growth factor one of the newer inventions, promotes faster and effective wound healing in diabetic foot ulcers. Its usefulness in bringing down the ulcer area is much better than other modalities of treatment. According to our statistical data about $80 \%$ of the ulcers either improved or healed by 4 weeks' time, which also goes in favour of these statements regarding platelet derived growth factor.

Infection one of the bad prognostic indicators of diabetic ulcer healing needs to be treated more effectively. Retrograde venous perfusion of antibiotics shows more promising results, in that it delivered an effective concentration of antibiotics at the wound site, thereby promoting ulcer healing in much better and faster rate. Hence, these platelet derived growth factor dressings and retrograde venous perfusion of antibiotics are better limb salvaging techniques, which can be employed in day-to-day practice.

All the patients in our study are screened for the presence high-risk pressure points in the same as well as the opposite foot. Special foot wears were prescribed to all our patients to prevent further ulcers in their foot. Education regarding foot care, which is utmost important in diabetic foot management is given to all of them.

By adequate control of blood sugar, proper foot care and judicious use of modalities like platelet derived growth factor, application and retrograde venous perfusion of antibiotics most of the diabetic limbs can be saved.

\section{REFERENCES}

[1] Delbridge L, Ctercteko G, Fowler C, et al. The aetiology of diabetic neuropathic ulceration of the foot. BJS 1985;72(1):1-6.

[2] Armstrong DG, Lavery LA, Harkless LB. Validation of a diabetic wound classification system. The contribution of depth, infection and ischemia to risk of amputation. Diabetic Care 1998;21(5):855-9.

[3] Bernstein EF, Fronek A, et al. Current status of noninvasive tests in the diagnosis of peripheral arterial disease. Surg Clin North Am 1982;62(3):47387.

[4] El-Tahawy AT. Bacteriology of diabetic foot. Saudi Med J 2000;21(4):344-7.

[5] Sinacore DR, Mueller MJ. Pedal ulcers in older adults with diabetes mellitus. Topics in Geriatric Rehabilitation 2000;16(2):11-23.

[6] Mcintosh A, Peters J, Young R. Prevention and management of foot problems in type 2 diabetes: clinical guidelines and evidence. Sheffield: University of Sheffield 2003.

[7] Armstrong DG, Lipsky BA. Diabetic foot infections: stepwise medical and surgical management. lnt Wound Journal 2004;1(2):123-32.

[8] Lipsky BA, Berendt AR, Deery HG, et al. Diagnosis and management of diabetic foot infections. Clin Infec Dis 2004;39(7):885-910.

[9] Abouaesha F, van Schie CH, Griffths GD, et al. Plantar tissue thickness is related to peak plantar pressure in high risk diabetic foot. Diabetes Care 2001;24(7):1270-4.

[10] Schaper NC. Diabetic foot ulcer classification system for research purposes: a progress report on criteria for including patients in research studies. Diabetes Metab Res Rev 2004;20(Suppl 1):S90-5.

[11] Langer K, Seidler C, Partsch H. Ultrastructural study of the dermal microvasculature in patients undergoing retrograde intravenous pressure infusions. Dermatology 1996;192(2):103-9.

[12] Jochmann W, Partsch H. Retrograde intravenous perfusion: technique and different variants. Wien Med Wochenschr 1993;143(7-8):167-70.

[13] Brunner M, Goring HD. Retrograde venous perfusion in ulcero-mutilating neuropathy. Hautarzt 2001;52(10 Pt 2):956-61. 
[14] Buhler-Singer S, Hiller D, Boateng B, et al. Disordered cutaneous microcirculation in diabetic neuropathic foot ulcer. Is modification by retrograde transvenous perfusion therapy possible? Hautarzt 1995;46(6): 400-5.
[15] Blue cross blue shield association. Recombinant and autologous platelet derived growth factors as a primary treatment of wound healing and other miscellaneous conditions. Medical policy referral manual, 2009. 